\title{
Pseudopregnancy in harp seals (Phoca groenlandica)
}

\author{
D. Renouf ${ }^{1^{*}}$, R. Taylor ${ }^{2}$ and R. Gales ${ }^{1,3 \dagger}$ \\ ${ }^{1}$ Ocean Sciences Centre and Psychology Department, Memorial University of Newfoundland, St John's, \\ Newfoundland, Canada AIC 5S7; ${ }^{2}$ Department of Forestry and Agriculture, Animal Health Division, \\ PO Box 7400, St John's, Newfoundland, Canada A1E 3Y5; and ${ }^{3}$ Division of Parks and Wildlife, GPO \\ Box 44A, Hobart, Tasmania 7001, Australia
}

\begin{abstract}
Concentrations of circulating progesterone were monitored in a captive breeding group of harp seals. Five females were monitored for 2 years, over which time they either became pregnant (four instances) or displayed an overt pseudopregnancy (five instances). Only one female exhibited consecutive pseudopregnancies. In all pseudopregnancies, serum progesterone values were high and remained high until July, which is close to the time when implantation normally occurs. After this time progesterone concentrations remained high, gradually declining to baseline values over the following four months. In the three females that were pregnant one year and pseudopregnant in the other year, the average progesterone concentration during pseudopregnancy was lower than that exhibited during pregnancy $(P<0.05)$. All females (except one) increased their mass, girth and condition index over the normal gestation period whether they were pregnant or pseudopregnant. The potential consequences of such a high rate of pseudopregnancy on the use of ovarian scars for estimating reproductive rates and population size are discussed.
\end{abstract}

\section{Introduction}

Pseudopregnancy is operationally defined as a prolonged increase of circulating progesterone concentrations in the absence of a fetus, often accompanied by various clinical signs typical of pregnancy, such as mass gain, mammary gland enlargement and lactogenesis. In some species the signs are covert, but in others, for example dogs, the female can display a full array of symptoms, including a mock birth, followed by attachment to inanimate objects, and heavy lactation (Arthur ef al., 1989). Ovulation and subsequent pseudopregnancy typically occur as a result of infertile mating, but can be induced by clitoral stimulation (Freeman and Neill, 1972; Pepe and Rothchild, 1974). During pseudopregnancy, progesterone is produced by the corpus luteum, the steroidogenic function of which, at least in laboratory animals (for example, rats and rabbits) is mediated by oestradiol, LH and prolactin surges (Freeman and Neill, 1972; Ross, 1978; Bill and Keyes, 1983; Arthur et al., 1989).

Pseudopregnancy in wild animals has not often been documented since it would be evident only when an apparently pregnant female did not produce offspring. Full confirmation necessitates the repeated acquisition of progesterone concentrations, as well as proof of the absence of a fetus. Gathering such information on marine mammals is practicable only with captive animals. There have been two reports of pseudopregnancy in seals. Noonan (1989) described cycles of increased progesterone (up to about $30 \mathrm{ng} \mathrm{ml}^{-1}$ ) with no

\footnotetext{
*Deceased.

${ }^{\dagger}$ Correspondence.

Revised manuscript received 23 June 1993.
}

evidence of a fetus upon $X$-ray in captive hooded seals (Cystophora cristata). Reijnders (1990) suggested that the increased progesterone concentrations (about $9.5 \mathrm{ng} \mathrm{ml}^{-1}$ ) in nonpregnant harbour seals (Phoca vitulina) which lasted throughout diapause could be interpreted as pseudopregnancy. The progesterone changes throughout pregnancy have been measured in other phocid species and show increases over the course of gestation, with a large decline a few days prepartum and then a fall to baseline values soon after the birth of the pup (Raeside and Ronald, 1981; Boyd, 1984a; Kirby, 1990; Reijnders, 1990).

Pseudopregnancy and pregnancy have been compared only once in the same species (harbour seals: Reijnders, 1990) since captive pinnipeds breed so rarely. In the present study, serum progesterone concentrations were monitored over 2 years in a group of captive harp seals (Phoca groenlandica). Some of the females in the colony became pregnant, while others displayed overt pseudopregnancy. This study compares the progesterone profiles and some associated morphological changes of pregnant, pseudopregnant and nonpregnant females.

\section{Materials and Methods}

Five female harp seals were captured during the pupping season in the Gulf of St Lawrence. Two adult females were acquired in March 1989, and three in March 1990. These females were flown with their approximately one-week old pups to the seal holding facility of the Ocean Sciences Centre of Memorial University in Logy Bay, Newfoundland. Two adult males were also acquired, one from the Quebec Aquarium in May of 1989, and the other in April 1991.

Downloaded from Bioscientifica.com at 04/26/2023 10:33:41AM 
Male and female seals and pups were housed communally in wooden outdoor tanks, ranging in size from $7.5 \mathrm{~m}$ diameter $\times 1.5 \mathrm{~m}$ deep to $12.3 \mathrm{~m}$ diameter $\times 2.5 \mathrm{~m}$ deep, through which sea water was continuously pumped at ambient temperature from the adjacent bay. The tanks were surrounded by wooden decking to which the seals had free access. When the water in these tanks froze over during the winter, the seals hauled out onto the ice pans as well as on to the decking.

The seals were fed herring (Clupea harengus) once a day on an ad libitum basis, and were given as much as they would eat during $2 \mathrm{~h}$ at midday, supplemented with Seatabs multivitamins (Pacific Research Labs, El Cajon, CA). The animals were weighed on a Howe platform scale $( \pm 250 \mathrm{~g}$ : Model 11717) once every two weeks from May 1990 to November 1990 and once a week thereafter. Axillary girths and straight lengths were also measured at this time (Scheffer, 1967). A condition index was calculated using the equation (axillary girth $\times 100$ )/length (McLaren, 1958; Scheffer, 1967; Sergeant, 1973).

Blood samples were taken from the hind flipper, usually twice each month, though occasionally more frequently, from April 1990 until April 1992. The only hiatus in this sampling regimen was in late winter, when ice prevented access to the seals. The blood was drawn into $10 \mathrm{ml}$ clot (silicone-treated) vacutainers, from which the serum was collected after centrifugation at $3080 \mathrm{~g}$ for $20 \mathrm{~min}$ and stored frozen in $1 \mathrm{ml}$ aliquots at $-70^{\circ} \mathrm{C}$ for subsequent analysis.

Progesterone was determined with a no-extraction, solid phase ${ }^{125}$ I-radioimmunoassay (sensitivity $0.05 \mathrm{ng} \mathrm{ml}^{-1}$ ) designed for the quantitative measurement of progesterone in serum or plasma (Coat-A-Count Progesterone; Diagnostic Products Corporation, Los Angeles, CA). With this assay, the ${ }^{125}$ I-labelled progesterone competes for a fixed time with progesterone in the subject sample for antibody sites in antibody-coated polypropylene tubes. The supernatant was decanted to terminate the competition and isolate the antibody-bound fraction of the radiolabelled progesterone; the radioactivity of the supernatant was measured in a gammacounter and converted to progesterone concentration via calibration.

The antiserum is highly specific for progesterone, with very low crossreactivity (maximum expected for 11-deoxycortisol $2.4 \%$ ) to other steroids that might be present in the samples. Lipaemia, bilirubin or haemolysis do not have any clinically significant effect on the assay.

\section{Statistical analysis}

The coefficients of variance (CV) were low and uniform, with no 'end of run' effect observed in assays involving up to 200 tubes. The interassay CVs (Lot OII QC) were low: $12.9 \%$; medium: $14.2 \%$; high: $8.2 \%$. The intra-assay $\mathrm{CVs}$ were low range: $0.5 \%$; entire range $<5.0 \%$.

All statistical analyses were performed on individual seals. One-way analysis of variance was used to compare mean progesterone concentrations across years. Pearson's productmoment correlation coefficients were calculated to compare the relationship between progesterone concentrations and morphometric variables in true pregnancy and pseudopregnancy.

\section{Results}

There were four pregnancies over the course of this study. Mating was never observed. One female (Emma) carried a pup to full-term, giving birth on 28 March 1992. The rest of the pregnancies ended prematurely with live pups being aborted (Florence: November 1991; Madeleine: February 1991; Sybil: December 1990). Madeleine died from an apparently congenital heart defect shortly after her pup was aborted.

All pregnancies were accompanied by an increase in serum progesterone concentrations (Fig. I). In the three animals that aborted their fetus, there was an abrupt increase in the already raised values, most often observed in October. Just before this peak, progesterone concentrations had declined in the three animals. Progesterone concentrations fell before all births and abortions, and returned to baseline values postpartum.

There was steroidal and morphological evidence of all the pseudopregnancies (Fig. 1). Babette showed an increase in mass during both seasons; however, she did not deliver a pup, and an X-ray in May 1992 confirmed the absence of a fetus. In both years monitored, her progesterone concentrations increased until July, falling thereafter until November. Similarly, in 1990 Emma and Florence showed pseudopregnancies with the chronology of progesterone changes similar to that shown by Babette. Emma also exhibited an increase in mass concurrent with changing hormone concentrations; Florence did not. Sybil showed no mass or progesterone change when she was not pregnant; her progesterone concentrations remained at baseline values after her pup was aborted in 1990 until the end of this study. The average progesterone concentrations in all pseudopregnancies were significantly lower than those reached by pregnant animals (Table 1 ).

There was no consistent relationship between progesterone concentrations and mass, axillary girth or condition index (Table 2). Only three significant correlations were evident. Mass was positively correlated with progesterone concentration for Sybil's pregnancy, but negatively related for Babette's first pseudopregnancy. The positive correlation between axillary girth and progesterone during Madeleine's pregnancy is based on only six observations. In most instances, there was a strong positive correlation between mass and axillary girth. Mass was positively associated with condition index except during Florence's pseudopregnancy and Madeleine's pregnancy for which there were only four condition indices.

\section{Discussion}

Phocid seals pup at the same time each year, and after a short lactation, mate and undergo a period of delayed implantation (Boyd, 1991). Harp seals are no exception to this pattern, giving birth to a single pup in March, nursing it for 10-14 days, followed by mating, and a 4-4.5-month diapause before implantation of the blastocyst in July or August (Lavigne and Kovacs, 1988; Stewart et al., 1989; Sergeant, 1991). Some workers contend that in marine mammals the corpus luteum is active during the entire gestation period and that the placenta, therefore, does not take over steroid production (Noonan, 1989; Kirby, 1990). Hobson and Boyd (1984)

Downloaded from Bioscientifica.com at 04/26/2023 10:33:41AM 
(a)

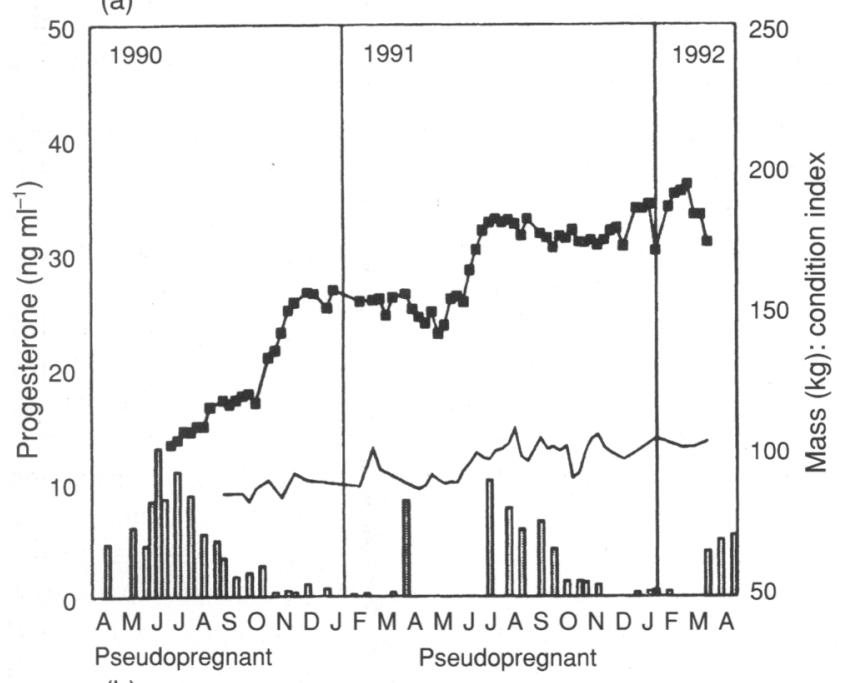

(b)

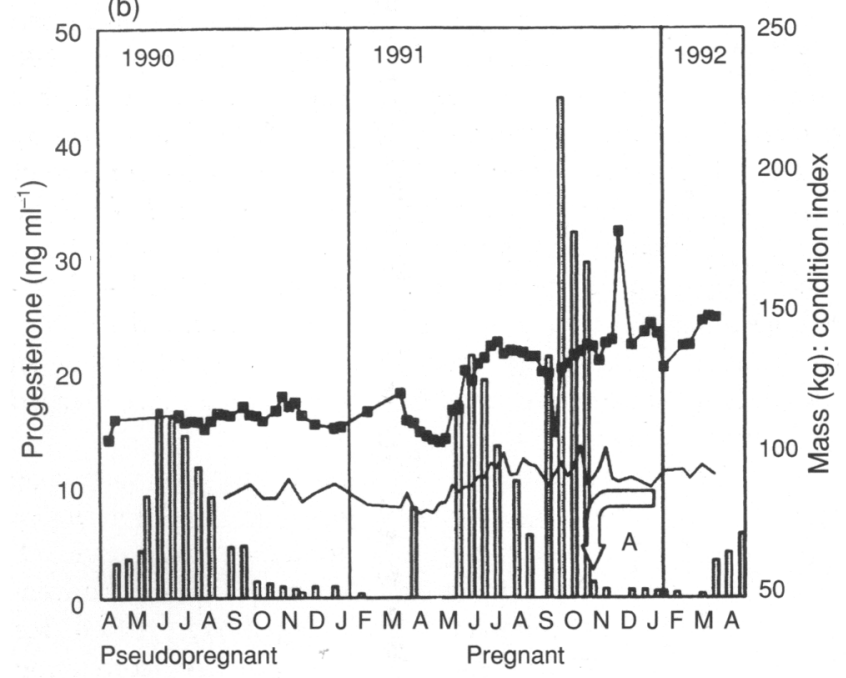

(c)

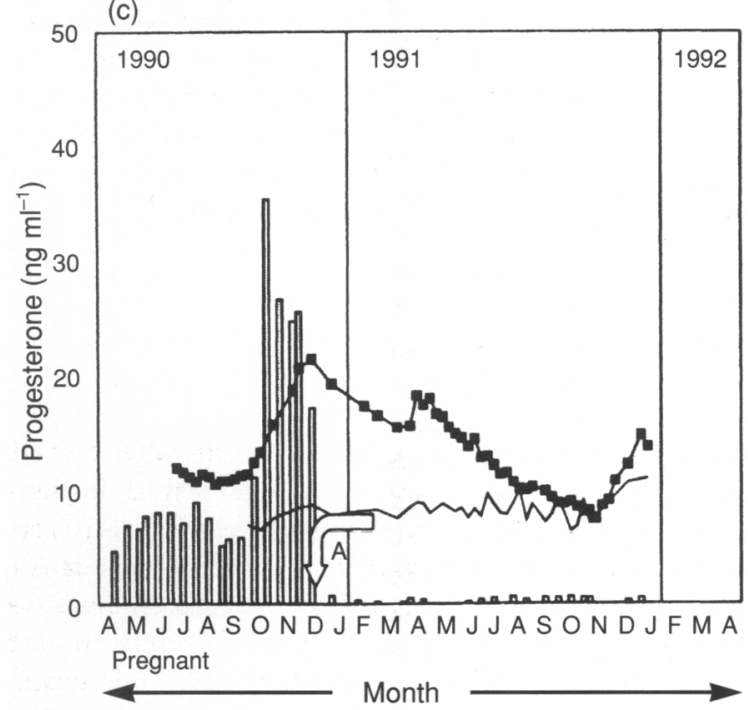

Fig. 1. (]) Serum progesterone concentrations (ng $\mathrm{ml}^{-1}$ ), (b) mass ( $\mathrm{kg}$ ) and (-) condition indices for female harp seals (a) Babette represents two years beginning with the breeding season in April 1990. Births and abortions are indicated on each graph by the annotated arrow (B: birth; A: Abortion). (d)

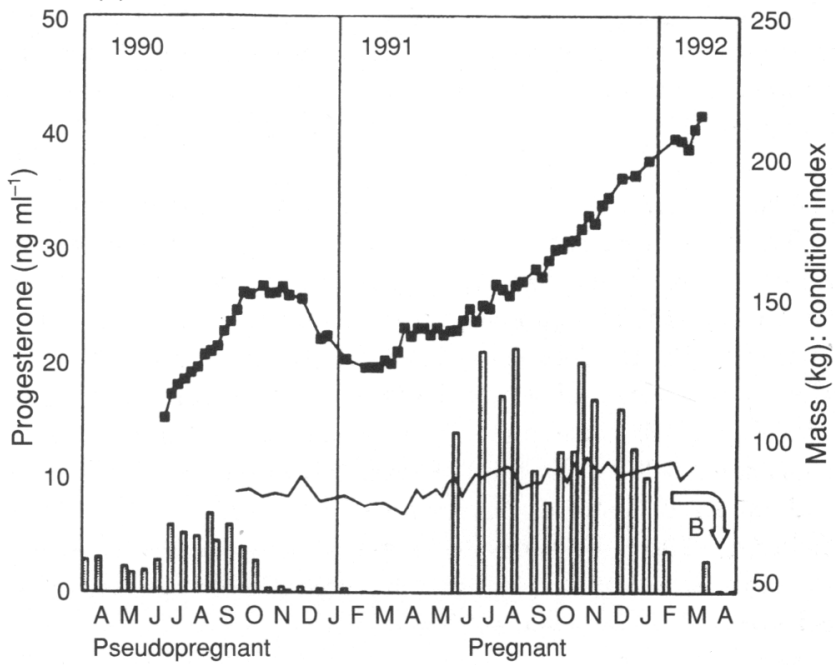

(e)

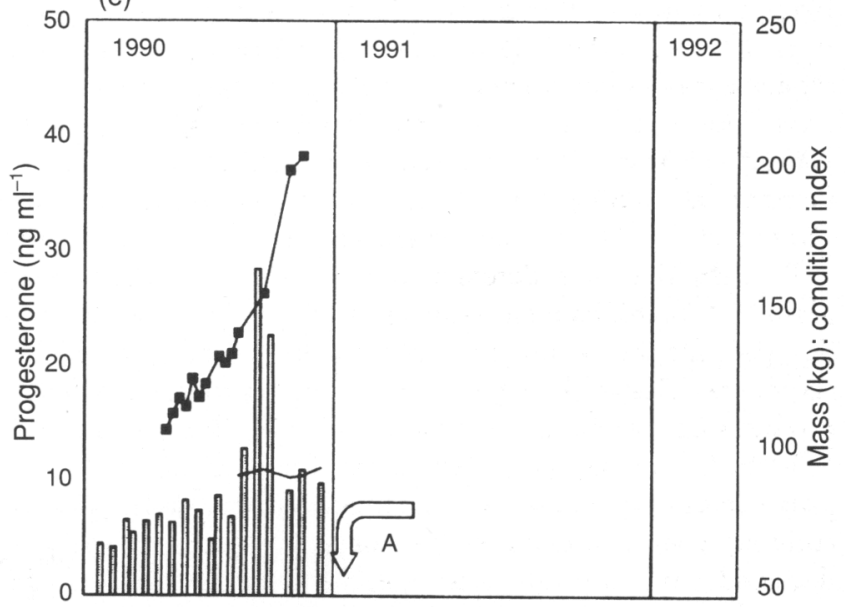

A M J J A SONDJFMAM J JASONDJFMA Pregnant
250

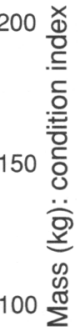


Table 1. Average serum progesterone concentrations ( $\mathrm{ng} \mathrm{ml}^{-1}$ ) in pregnant and pseudopregnant harp seals

\begin{tabular}{lccc}
\hline Animal & Year I (1990-1991) & Year 2 (1991-1992) & ANOVA \\
\hline Emma & $2.59(2.15)$ & $13.27^{*}(5.71)$ & $F=66.82$ d.f. $=1,36 P<0.001$ \\
Florence & $5.99(5.63)$ & $12.20^{*}(12.54)$ & $F=4.53$ d.f. $=1,43 P=0.039$ \\
Sybil & $9.90^{*}(9.43)$ & $0.45 \quad(0.12)$ & $F=14.92$ d.f. $=1,36 P<0.001$ \\
Madeleine & $9.23^{*}(6.25)$ & & \\
Babette & $4.15(3.70)$ & $4.03 \quad(3.64)$ & $F=0.01$ d.f. $=1,38 P=0.918$ \\
\hline
\end{tabular}

*Years in which the animaI was pregnant.

Values in parentheses are standard deviations.

Table 2. Pearson product-moment correlation coefficients among progesterone concentrations, body mass, axillary girth and condition index for individual harp seals

\begin{tabular}{|c|c|c|c|c|}
\hline & Emma 1991-1992 & Florence 1991-1992 & Sybil 1990-1991 & Madeleine 1990-1991 \\
\hline \multicolumn{5}{|l|}{ Pregnancies } \\
\hline Progesterone $\times$ mass & $\begin{array}{l}-0.30 \\
(n=13)\end{array}$ & $\begin{array}{l}+0.21 \\
(n=11)\end{array}$ & $\begin{array}{l}+0.74^{*} \\
(n=12)\end{array}$ & $\begin{array}{l}+0.31 \\
(n=10)\end{array}$ \\
\hline Progesterone $\times$ axillary girth & $\begin{array}{l}-0.41 \\
(n=13)\end{array}$ & $\begin{array}{l}+0.30 \\
(n=11)\end{array}$ & $\begin{array}{l}+0.42 \\
(n=7)\end{array}$ & $\begin{array}{l}+0.90^{*} \\
(n=6)\end{array}$ \\
\hline Progesterone $\times$ condition index & $\begin{array}{l}-0.41 \\
(n=13)\end{array}$ & $\begin{array}{l}+0.34 \\
(n=11)\end{array}$ & $\begin{array}{l}-0.46 \\
(n=5)\end{array}$ & $\begin{array}{l}+0.48 \\
(n=5)\end{array}$ \\
\hline Pseudopregnancies & Emma 1990-1991 & Florence 1990-1991 & Babette $1990-1991$ & Babette 1991-1992 \\
\hline Progesterone $\times$ mass & $\begin{array}{l}-0.32 \\
(n=17)\end{array}$ & $\begin{array}{l}-0.36 \\
(n=14)\end{array}$ & $\begin{array}{c}-0.83^{*} \\
(n=16)\end{array}$ & $\begin{array}{l}-0.30 \\
(n=15)\end{array}$ \\
\hline Progesterone $\times$ axillary girth & $\begin{array}{l}+0.08 \\
(n=14)\end{array}$ & $\begin{array}{l}+0.08 \\
(n=10)\end{array}$ & $\begin{array}{l}-0.41 \\
(n=12)\end{array}$ & $\begin{array}{l}-0.26 \\
(n=13)\end{array}$ \\
\hline Progesterone $\times$ condition index & $\begin{array}{l}+0.27 \\
(n=10)\end{array}$ & $\begin{array}{l}+0.44 \\
(n=8)\end{array}$ & $\begin{array}{l}-0.42 \\
(n=9)\end{array}$ & $\begin{array}{c}-0.37 \\
(n=13)\end{array}$ \\
\hline Pregnancies & Emma 1991-1992 & Florence 1991-1992 & Sybil 1990-1991 & Madeleine 1990-1991 \\
\hline Mass $\times$ girth & $\begin{array}{c}+0.89^{*} \\
(n=36)\end{array}$ & $\begin{array}{l}+0.75^{*} \\
(n=39)\end{array}$ & $\begin{array}{c}+0.81^{*} \\
(n=14)\end{array}$ & $\begin{array}{l}+0.93^{*} \\
(n=6)\end{array}$ \\
\hline Mass $\times$ condition & $\begin{array}{l}+0.64^{*} \\
(n=34)\end{array}$ & $\begin{array}{l}+0.60^{*} \\
(n=39)\end{array}$ & $\begin{array}{l}+0.87^{*} \\
(n=9)\end{array}$ & $\begin{array}{l}-0.48 \\
(n=4)\end{array}$ \\
\hline Pseudopregnancies & Emma 1990-1991 & Florence 1990-1991 & Babette 1990-1991 & Babette 1991-1992 \\
\hline Mass $\times$ girth & $\begin{array}{l}+0.62^{*} \\
(n=20)\end{array}$ & $\begin{array}{l}-0.27 \\
(n=16)\end{array}$ & $\begin{array}{c}+0.71^{*} \\
(n=18)\end{array}$ & $\begin{array}{c}+0.85^{*} \\
(n=37)\end{array}$ \\
\hline Mass $\times$ condition & $\begin{array}{l}+0.67^{*} \\
(n=11)\end{array}$ & $\begin{array}{l}-0.39 \\
(n=11)\end{array}$ & $\begin{array}{l}+0.65^{*} \\
(n=11)\end{array}$ & $\begin{array}{l}+0.77^{*} \\
(n=37)\end{array}$ \\
\hline
\end{tabular}

$* P<0.05$

For the pregnancies, only the weeks until the pup was aborted were used to calculate the correlations with progesterone.

reported luteal growth throughout pregnancy in grey seals. However, they maintained that the corpus luteum does not necessarily produce progesterone for the entire period of enlargement, and that its progestagenic function is taken over by the placenta. Hypertrophy of the corpus luteum during the last two months of pregnancy could be the result of the build-up of large lipid-filled nonsteroidogenic cells (Boyd, 1991). Survival and enlargement of the corpus luteum during the last 3-5 months of pregnancy could be the result of the secretion of chorionic gonadotrophins from the placenta. The end of pseudopregnancy may occur at the time when, in a pregnant seal, the role of maintaining pregnancy through increased progesterone concentrations passes from the corpus luteum to the placenta. Boyd (1991) interpreted the 210 day increase in progesterone concentrations, reported by Noonan and Ronald (1989), as an indication of the functional lifespan of the corpus luteum in hooded seals. This is similar to the interpretation made by Reijnders (1990) of the 4-5 month progesterone increases in his nonpregnant harbour seals. The data reported in the present study of harp seals support these views, and suggest that the corpus luteum produces progesterone for about seven months, and that the placenta becomes Downloaded from Bioscientifica.com at 04/26/2023 10:33:41AM 
steroidogenic, thereafter. This is evident by the similarity of the progesterone changes observed until October-November, that is, the steep rise at this time in pregnant seals, but the decline in pseudopregnant animals.

Collection of blood samples began too late in 1990 to see the rise in progesterone concentrations indicative of ovulation in that season. It was apparent for Babette and Florence in subsequent seasons (4 April 1991 and 24 March 1992, respectively); however, there is no evidence of Sybil having ovulated in 1991, which may explain why she did not exhibit a pseudopregnancy in that year. Unfortunately, there were no samples for this time in 1991 for Emma, and in 1992 her progesterone concentrations had not risen by the time this study ended.

A fall in progesterone concentrations $6-7$ months after mating is clear in the pregnancies that survived for this period. Although falling progesterone values during the final days of gestation seem typical, it is possible that the early decrease observed in this study was pathological, since only one pup was carried to full term. Emma's pup was delivered without incident, and nursed normally for about $24 \mathrm{~h}$ on what appeared to be an ample milk supply. However, it died a day later for reasons that were not determined upon necropsy.

It is difficult to assess whether the changes in mass shown during most pseudopregnancies were mediated by progesterone or were a consequence of the large seasonal changes in body condition that are not related to pregnancy. Adult males fatten over the winter to a similar extent as pregnant females, and juveniles also show large seasonal changes in body mass (Renouf et al., 1993). The fact that Sybil's mass declined during year two when her progesterone concentration remained at baseline values suggests some hormonal involvement in the annual cycle of fat acquisition. Boyd (1984b) proposed that endocrine changes associated with implantation induce metabolic effects that cause fat to be stored. It seems from the present data that implantation is not necessary for such changes, although a functional corpus luteum might be. The increase in mass seen in the seals in this study began before the time when implantation should have occurred. However, the low correlation between progesterone values and changes in mass and body condition suggests, not surprisingly, that the dynamics of fat acquisition and loss involve more than just this hormone.

Boyd (1991) proposed that the reproductive system is essentially dormant during diapause and is reactivated at implantation. Insofar as progesterone increases are an indication of the activity of the reproductive system, it seems that in harp seals, at least, the reproductive system is not entirely quiescent during the interval between mating in March and implantation in late July. Boyd also found raised progesterone concentrations during diapause in grey seals (Boyd, 1983, 1984a). The increase in progesterone values observed in June 1991 in two of the pregnancies (Emma and Florence) could have been interpreted as a sign of enhanced activity upon implantation were it not that similarly timed rises are evident in all the pseudopregnancies.

It could be argued that the high rate of pseudopregnancy in this study and that of Noonan (1989) is a result of the stress of holding seals in captivity. However, this seems unlikely since we have found no evidence of pseudopregnancy in the colony of harbour seals that are held in the same facility as the harp seals described herein. This group of harbour seals has one adult female that has produced a pup in all but one year since 1983.

It is therefore possible that the corpus luteum normally produces a pseudopregnancy in the wild when infertile matings occur, or when pregnancy is aborted. It is extremely important that the normal incidence of pseudopregnancy in wild populations is determined, since reproductive rates in pinnipeds are conventionally ascertained by examination of corpora lutea and albicantia (Sergeant, 1966, 1991; Bengston and Siniff, 1981; Boyd, 1984a, 1985). Both of these ovarian scars would also be evident in pseudopregnancy. In any species that displays a significant rate of pseudopregnancy, errors in determining pregnancy rates, either by progesterone concentrations, or by examining ovarian scars, would increase in times of reduced food availability, given that aborted pregnancy with prolonged luteal function is more likely when condition is compromised. This is particularly relevant at the present time for the harp seal, given the current critical reductions in some Northwest Atlantic fish stocks, and the call for a renewed hunt as a means of reducing populations of seals. In any species, missed pseudopregnancy and consequent falsely raised fertility and fecundity rates would have profound consequences for the modelling of population dynamics and energy flow.

The authors would like to thank E. Noseworthy, P. Dunphy and G. Dalton for their unfailing assistance. The advice of I. L. Boyd (British Antarctic Survey) and L. Astheimer (University of Woollongong) was especially instructive. This work was supported by grants to D. Renouf from the Canadian Centre for Fisheries Innovation and the Natural Science and Engineering Research Council (A6364) and is Ocean Sciences Contribution number 179.

\section{References}

Arthur G, Noakes D and Pearson H (1989) Veterinary Reproduction and Obstetrics, Baillière Tindall, London

Bengston J and Siniff D (1981) Reproductive aspects of female crabeater seals (Lobodon carcinophagus) along the Antarctic Peninsula Canadian Journal of Zoology 59 92-102

Bill $C$ and Keyes P (1983) $17 \beta$-Estradiol maintains normal function of corpora lutea throughout pseudopregnancy in hypophysectomized rabbits Biology of Reproduction 28 608-617

Boyd IL (1983) Luteal regression, follicle growth and the concentration of some plasma steroids during lactation in grey seals (Halichoerus grypus) Journal of Reproduction and Fertility 69 1095-1100

Boyd IL (1984a) Development and regression of the corpus luteum in grey seal (Halichoerus grypus) ovaries and its use in determining fertility rates Canadian Journal of Zoology 62 1096-1100

Boyd IL (1984b) The relationship between body condition and the timing of implantation in pregnant grey seals (Halichoerus grypus) Journal of Zoology (London) 203 113-123

Boyd IL (1985) Pregnancy and ovulation rates in grey seals (Halichoerus grypus) on the British coast Joumal of Zoology (London) 205 2265-2272

Boyd IL (1991) Environmental and physiological factors controlling the reproductive cycles of pinnipeds Canadian Journal of Zoology 69 1135-1148

Freeman $M$ and Neill $J$ (1972) The pattern of prolactin secretion during pseudopregnancy in the rat: a daily nocturnal surge Endocrinology 90 1292-1294

Hobson BM and Boyd IL (1984) Gonadotropin and progesterone concentrations in placentae of grey seals (Halichoerus grypus) Journal of Reproduction and Fertility 72 521-528

Downloaded from Bioscientifica.com at 04/26/2023 10:33:41AM 
Kirby V (1990) Endocrinology of marine mammals. In Handbook of Marine Mammal Medicine: Health, Disease and Rehabilitation, pp 303-35I Ed. L Dierauf. CRC Press, Florida

Lavigne DM and Kovacs KM (1988) Harps and hoods. Ice-breeding seals of the Northwest Atlantic, University of Waterloo Press, Waterloo

McLaren I (1958) The biology of the ringed seal (Phoca hispida) (Schreder) in the eastern Canadian Arctic Bulletin of the Fisheries Research Board of Canada No. 118

Noonan LM (1989) Determination of plasma estrone sulfate and progesterone for female hooded seals and plasma testosterone for male hooded seals, Cystophora cristata MSc Thesis, University of Guelph

Noonan L and Ronald K (1989) Determination of estrone sulphate, progesterone and testosterone for hooded seals, Cystophora cristata. In Proceedings of the Eighth Biennial Conference on the Biology of Marine Mammals, Pacific Grove, California pp 46 (Abstract). Society for Marine Mammalogy

Pepe G and Rothchild I (1974) A comparative study of progesterone levels in pregnancy in various types of pseudopregnancy in the rat Endocrinology 95 275-279

Raeside JI and Ronald K (1981) Plasma concentrations of oestrone, progesterone and corticosteroids during late pregnancy and after parturition in the harbour seal Phoca vitulina Journal of Reproduction and Fertility 61 135-139
Reijnders PJH (1990) Progesterone and oestradiol-17 $\beta$ concentration profiles throughout the reproductive cycle in harbour seals (Phoca vitulina) Journal of Reproduction and Fertility 90 403-409

Renouf D, Gales R and Noseworthy E (1993) Seasonal variation in energy intake and condition of harp seals: is there a harp seal morph? Problems for bioenergetic modelling Journal of Zoology 230 513-528

Ross G (1978) Essentials of Human Physiology. Year Book Medical Publishers, Chicago

Scheffer V (1967) Standard measurements of seals Joumal of Mammalogy 48 $459-462$

Sergeant DE (1966) Reproductive rates of harp seals (Pagophilus groenlandicus) (Erxleben) Joumal of the Fisheries Research Board of Canada 23 757-766

Sergeant DE (1973) Feeding, growth and productivity of Northwest Atlantic harp seals (Pagophilus groenlandicus) Journal of the Fisheries Research Board of Canada 30 17-29

Sergeant DE (1991) Harp seals, man and ice Canadian Special Publication in Fisheries and Aquatic Science No. 114 Department of Fisheries and Oceans, Ottawa

Stewart REA, Stewart B, Lavigne DM and Miller G (1989) Fetal growth of Northwest Atlantic harp seals, Phoca groenlandica Canadian Journal of Zoology 67 2147-2157 